\title{
Cooperative Learning Group for English Teachers: One way of Supporting Under-qualified Teachers
}

\author{
Puji Rahayu \\ Islamic University of Indonesia
}

\begin{abstract}
The fact that English teachers in Indonesia especially in remote area are underqualified is not debatable. They are not only incapable of teaching well but quite a lot of them also still need help in their English proficiency. Asking them to take an English class for them is almost impossible. There must be ways of developing their professionalism while they are performing as teachers.

Building a cooperative leaming group for English teacher will make them improved in both the knowledge and skills in teaching because of the very slogan of cooperative learning, which is "sink and swim together". Each group will be responsible for the improvement of all members because their success is determined by the success of the group and the group also determines the success of the individual. This movement will be much more effective if it is used as one of the criteria of kenaikan pangkat.
\end{abstract}

Key words: cooperative learning, English teachers 


\section{A. Introduction}

During a placement test at an English course in Yogyakarta where I worked for more than five years, I was shocked by a woman who wanted to take an English course at the institution. When asked what she did for a living, she said: "I am an English teacher at SMA X." What shocked me was the fact that she could not even make grammatically good simple sentences! I put her at the lowest level, beginner. Gosh!! What will happen to her students' English proficiency if taught by such teacher!

Teaching her after the placement test, I had the opportunity to know her more. She was graduated from an English education department of a private university in Yogyakarta. She accepted an offer of a friend to teach English at a high school of Yayasan $\mathrm{X}$ after leaving academic life for more than five years. She admitted that when leaving the university, her English was not good and she was not ready to teach.

The case of her is not the only one, I suppose. There might be more teachers sharing the same experience that they are not confident enough with their English when teaching. They do not teach English using English but Bahasa Indonesia which should not be the medium of English class instruction, or if they teach in English major mistakes still exist in their sentences. It happens because they do not have adequate knowledge of the English language. As a result, the students will not be able to master English well since they do not get good model from the teacher. Even when the teacher is a good model, students still cannot be as good as the teacher since it is only around $80 \%$ at the most of what the teacher gives can be absorbed by the students.

The problem of under qualified English teachers also occurs in elementary schools. The regulation that English is now taught in elementary schools as a muatan lokal requires more English teachers. The government, however, does not support the availability of the English teachers yet: As a result, some elementary schools contract an English teacher by their own budget. If they are lucky and have appropriate budget, they will get good English teachers who manage to teach their students well due to their excellent proficiency in both English and English teaching. Other schools, on the other hands, do not have enough budgets to hire good English teachers. As a result, the students are taught by under qualified English teachers, because it is expensive to hire the qualified ones, or by non English teachers. We can imagine the result!!

Talking about under qualified teachers is not only in the field of English. There is a trend that in almost all levels of education, there are a lot of under qualified teachers. It is reported that regarding Indonesian teacher quality portrays a gloomy picture, showing that many teachers in Indonesia are under-qualified and poorly trained. According to the report from the 2004/2005 National Education Department, 30.53\% of high school teachers in Indonesia are not qualified to teach due to low level of education. Furthermore, teachers who do not have the qualification sometimes do not master the content of their subject matter or process adequate training and knowledge regarding the needs of young people and how they learn (Sampoerna Foundation). To make matter 
worse, they: are paid such low salaries that they need to find side jobs. It makes professional development impossible since they do not have enough time to carry it out.

Bambang Sudibyo, who was the National Minister of Education, reported that around $65 \%$ of teachers did not meet the qualification to fulfill the national standard of education. There are many teachers teaching the subject outside their competence (2006). Of the $35 \%$ of qualified teachers, the distribution is not even in all areas in Indonesia. Director General of Education Quality Improvement (Mutendik) at the National Education Ministry, Fasli Jalal (in Koran Tempo) said that teachers are not evenly. distributed across the country, especially in remote areas (Tempo, 2007). Qualified teachers tend to work in big cities with good facilities. As a result, not enough qualified teachers in remote areas.

Richards (2001) points out a number of problems comimonly encountered by under-qualified teachers, such as:

* They lack knowledge of what to expect of pupils, what challenges to set, and what difficulties to anticipate.

* They tend to work from the textbook rather than in terms of pupil attainment levels. :

* They lack practical classroom management routines to keep pupils on task.

* Their concern with control makes it difficult for them to focus on pupil learning.

* They lack an established "pedagogical content knowledge".

* They lack the practical experience from which to construct personal meanings for theoretical or specialized terms.

* They lack a coherent system of concepts with which to think about teaching.

* They lack a specialized vocabulary with which to analyze and discuss teaching (p. 211).

That fact about under qualified teachers in Indonesia, including in Yogyakarta, which is well known as an education city, forces us to cater professional development relevant to them. Some municipalities, Bantul for example, give incentives to teachers who are willing to continue their study. Teachers do not need to pay full tuition fee if they want to take master degree in education. A lot of teachers take the chance of pursuing their study while quite many who do not wan to continue their education due to some reasons. They are not young anymore to study and taking a master degree is not only a matter of paying the tuition fee. They will have to pay for other stuffs relating to materials and other expenses than the tuition fee. They do not have that extra budget.

Professional development or quality improvement, however, is a must despite those conditions mentioned above. Buchory, (Kedaulatan Rakyat, 25/07/06) said that 'teachers' quality improvement is very important nowadays. Therefore, teachers who have not fulfilled academic requirements as stipulated in the Teachers and Lecturers Law. should adapt themselves of their own free will. 
Quality improvement and certification are indispensable". Indeed, under qualified teachers need to improve their qualities by carrying out professional development.

\section{B. Teacher's Professional Development}

To be qualified and professional teachers, we have to observe our duty as a teacher holding some principles. Law No. 14/2005 (in Madya, 2007) on Teachers and Lecturers stipulates that:

"the teaching profession at school and higher learning institutions shall be carried out based on the following principles (Article 7): (a) possess a talent, interest, dedicating will, and idealism; (b) possess a commitment to improving education quality, belief, piety, and noble character; (c) possess a relevant academic qualification and educational background; (d) possess competencies required by the teaching duties; (e) possess responsibility for carrying professional tasks; (f) receive an income determined according to working achievements; (g) have opportunities to carry a sustainable professional development and lifelong learning; (h) have a legal protection in carrying out professional tasks; and (i) have a professional organization authorized to organize things related to teachers' professional tasks.

The law indicates that there are at least nine principles that teachers should consider when carrying out their job, one of which is possessing competencies required by the teaching duties. If they are English teachers, they will have to be good at English macro skills, listening, speaking, reading, and writing, so as to teach well. If they are not, the students will not get the highest benefits of mastering English. In order that the students do not experience such disadvantages, teachers should be prepared well when they take their bachelor degree of education. When they are working, they should also be developed too.

The purpose of pre-service and in-service teacher supervision is often to evaluate the teacher's teaching, offer suggestions on the best way to teach, direct or guide the teacher, and model teaching behaviors. Although some teachers appreciate this directive supervisory approach, it does have limitations. The most outstanding limitation is that the supervisor's prescriptions about teaching force teachers to comply with what the supervisor think they should do in the classroom. As the decision making is mostly supervisor, the directive approach does not allow teachers to develop the skills they need to make informed decisions about how to teach.

Ministry of Education of the United States defines professional development as a process by which teachers engage in "active learning that builds their knowledge; understanding, and ability (National Science Education Standards, 1996: 56). Brockerville, on the other hand, defines professional development as a dynamic process bringing the person into a new level of understanding and heighten awareness of the 
context in which teachers work that may compel them to examine accepted policies and routines. From the two definitions of professional development we may conclude that P.D will improve both our knowledge of the subject matter and understanding of our profession in teaching. Doing this, under qualified English teachers will gain benefits in improving their subject matter.

There are some ways of professional development, which can be used to better the condition of teacher's quality in Indonesia. In serving as a professional teacher, one should develop herself by doing some activities that will improve their professionalism. In his book entitled.Curriculum Development and Language Teaching, Richards (2001:206) mentions some opportunities for a professional development. They are

- Conference participation. In these activities, teachers can create networks with other teachers and learning about trends, issues, and practices.

- Workshops and in-service seminars. In this activity, teachers in a certain institution can attend such programs. To fit their needs, they can initiate a workshop or seminar of their interest.

- Reading group. Teachers can have better understanding on a certain topic in this reading group since they can share what they read to others.

- Peer observation. It can be used to gain critical reflection and discussion on teaching approaches.

- Writing about teaching. Teachers can write a journal on their teaching and they can share with others in a certain group.

- Project work. Teachers can be given opportunities to make teaching materials, media, videos, or other teaching resources.

- Action research. Teachers can conduct a small-scale research on their teaching.

Teachers can choose which activity is best for them. Having chosen one or two or more; teachers should not be satisfied with the result gained since professional development is not product oriented. It is process oriented, instead. When a certain teacher has reached a certain level of professionalism, $\mathrm{s}(\mathrm{he})$ still needs to improve it.

Professional development must be viewed as process-oriented rather than product-oriented. Educators need a model of professional development that brings groups of teachers together regularly to reflect on who we are, what we value, who we teach, what we teach, how we teach and why we teach the way we do. It means that attending seminars and workshops is not certainly' enough since they cannot truly see' their own practice and better it directly. What they get from seminars and workshops are only possibilities that may be successful or unsuccessful. Thus, teachers need a process which can improve their quality of teaching and even more internalize a moral value of self reflection.

Teachers can carry out their professional development individually or in group: There are of course advantages and disadvantages when choosing either individual or group based professional development. Doing it in the group, however, teachers will at 
least have friends who will monitor the process and give suggestions when it is needed. That is the reason why a professional group is needed: Yet, what kind of group is needed. In the following section, we will discuss the possibility of having a cooperative learning group for teachers.

\section{Cooperative Learning Group for Teachers}

Cooperative learning is commonly used in grouping students so that they can work together to achieve their common goals. Every member of the group is responsible for the success of the group and each individual. The score of each member is determined by the performance of all individuals and the group. Since their success is also influenced by other members' success, every body in the group will of course help one another so that all succeed. No one makes use of other's effort for their own benefits. They will always "sink and swim" together (Johnson, 1998a)

Using cooperative learning in grouping teacher will also be of good idea to let them improve together. It will help the teachers in the group to improve since the other member will not let them work alone. According to Johnson et. al. (1993), cooperative learning also means the instructional use of small groups so that students work together to maximize their own and each other's learning. Cooperative efforts result in participants striving for mutual benefit so that all group members gain from each other's efforts (Your success benefits me and my success benefits you), recognizing that all group members share a common fate (We all sink or swim together here), knowing that one's performance is mutually caused by oneself and one's colleagues (We can not do it without you), and feeling proud and jointly celebrating when a group member is recognized for achievement (We all congratulate you on your accomplishment!).

Not all group works are simply cooperative. There is a difference between "working together in a group" and working together cooperatively. A group of teachers sitting at the same table doing their own work, but free to talk with each other as they work, is not a cooperative group as there is no positive interdependence. (Perhaps it could be called individualistic learning with talking.) There needs to be an accepted common goal on which the group will be rewarded for their efforts. In the same way, a group of teachers who have been assigned to do a report where only one teacher cares, does all the work and the others go along for a free ride, is not a cooperative group. A cooperative group has a sense of individual accountability that means that all teachers need to know the material or spell well for the group to be successful. Putting teachers into groups does not necessarily gain positive interdependence and/or individual accountability; it has to be structured and managed by a person called facilitator.

The first characteristic of cooperative learning is positive interdependence- the feeling among group members that by helping other group members, they are helping themselves. If members feel they are positively interdependent with their group mates, they are more likely to stay on task and to help one another learn. Helping one another to get success will increase the quality of their learning. 
The second one is individual accountability - the feeling that all group members are responsible for participating in and learning from the activity. If students feel individually accountable, they are more likely to try to learn, rather than letting others do the work and the learning for them. There will be no one free riding on others:

The third one is promotive interaction, the interaction that students work together in which they promote each other's success by sharing resources and helping, supporting, encouraging, and applauding each other's efforts to achieve. There are important cognitive activities and interpersonal dynamics that can only occur when students promote each other's learning. This includes orally explaining how to solve problems, teaching one's knowledge to others, checking for understanding, discussing concepts being learned, and connecting present with past learning. Each of those activities can be structured into group task directions and procedures.

The fourth characteristic is interpersonal and small group skills. Cooperative learning is inherently more complex than competitive or individualistic learning because students have to engage simultaneously in task work (learning academic subject matter) and teamwork (functioning effectively as a group). Leadership, decision-making, trustbuilding, communication, and conflict-management skills empower students to manage both teamwork and task work successfully.

The fifth basic element of cooperative learning is group processing. Group processing exists when group members discuss how well they are achieving their goals and maintaining effective working relationships. Groups need to describe what member actions are helpful and unhelpful and make decisions about what behaviors to continue or change. Continuous improvement of the processes of learning results from the careful analysis of how members are working together and determining how group effectiveness can be enhanced.

Applying group work with such characteristics for the teachers will certainly improve their performance in both subject matter and teaching skills. Teachers will work together to achieve the common goal, being qualified teachers. Each group member will help one another to make betterment in their professionalism in both the subject matter and teaching technique.

Pointing out the importance of getting involved in a teacher group, Stigler \& Hiebert(1999:146) say

"To do more than improve teaching in their own classrooms, to raise the standard of good teaching within the profession-this demands that teachers work together, sharing what they learn in the classrooms to help one another learn more. It demands that they. assume responsibility for building the professional knowledge base. 


\section{How the Design Work}

As stated before that teachers need to get involved in a cooperative learning group so that they can get improved. The group, however, needs to be designed so as to be heterogeneous in the level of professionalism of the members. By doing so, teachers who are under-qualified can get benefits from those who are already qualified without leaving their individual accountability as the member of the group. To get the most benefits in their cooperative learning group, however, a supervisor should watch them and the design should be determined at the very beginning of the group formation.

There are some considerations or steps that have to be taken into account in forming cooperative learning group for teachers. They are:

1. A supervisor, the head master for example, groups teachers based on the subject they teach. If there is only one teacher of a certain subject, he can group the teacher with a teacher in similar subject. The composition must be good teachers together with the under-qualified ones.

2. The group meets and decides what activities to be carried out during a certain period of time. The supervisor can help at this step especially when it becomes the policy of the school. The activities can be in the form of regular discussions, workshops and trainings, action research, team teaching, and instructional projects.

3. The supervisor monitors the group when carrying out the activities and assesses the progress. The assessment is not only based on the performance of the group but should also be based on the individual performance. The result of the assessment can be used to determine the improvement of the teacher. This can be included in penilaian angka kredit. 


\section{Bibliography}

Fullan, M. (2001) The New Meaning of Educational Change ( $3^{\text {nd }} E d$.) Teachers College: Columbia University New York and London

Johnson, D.W., Johnson, R.T., and Holubec, E.J. 1993. Circles of learning ( $4^{\text {th }}$ ed.). Edina, MI: Interaction Book Company.

http://www.sampoernafoundation.org/content/view/206/57/lang,en/ retrieved at 15:25. on 30 March 2008

Gebhard, Jerry G. \& Akiko Ueda-Motonaga (1992). The power of observation: 'Make a wish, make a dream, imagine all the possibilities!' in Collaborative Language Learning and Teaching Edited by David Nunan, Cambridge University Press

Koran Tempo, 25 January 2007

Madya, S. (2007) Certification for Teachers and Lecturers and Its Implications for Staff Development in Journal of English and Education, Vol 1. July 2007, English Study Program Diploma III Universitas Islam Indonesia, Yogyakarta, 2007

National Science Education Standards (1996). Washington, D.C.: National Academy Press.

Richards, Jack C.(2001). Curriculum Development in Language Teaching, USA: Cambridge University Press

Richards, J. C., \& Lockhart, C. (1994). Reflective teaching in second language classrooms. Cambridge: Cambridge University Press.

Sinar Harapan 231106 taken from http://www.sampoernafoundation.org/ retrieved 30 March 2008 06:30 